\title{
IMPLEMENTASI PROGRAM KEWIRAUSAHAAN MELALUI PEMBELAJARAN PRAKARYA DAN KEWIRAUSAHAAN DI SMA NEGERI 2 BANGUNTAPAN BANTUL
}

\author{
Tugino $^{1}$ dan Enung Hasanah ${ }^{2}$ \\ 1,2 Magister Manajemen Pendidikan, Universitas Ahmad Dahlan Yogyakarta, Indonesia. \\ J1. Pramuka No.42, Sidikan, Umbulharjo Yogyakarta \\ ${ }^{1}$ Email: tuginomumtaz@gmail.com \\ ${ }^{2}$ Email: enung.hasanah@mp.uad.ac.id
}

\begin{abstract}
ABSTRAK
Penelitian ini bertujuan untuk mengeksplorasi proses implementasi program kewirausahaan melalui pembelajaran prakarya dan kewirausahaan di SMA Negeri 2 Banguntapan Bantul. Penelitian ini menggunakan pendekatan kualitatif deskriptif. Pengumpulan data dilakukan melalui wawancara, observasi, dan analisis dokumen. Wawancara dilakuan terhadap kepala sekolah, wakil kepala sekolah, guru, siswa, dan orang tua siswa. Kami melakukan analisis data mengacu pada tulisan Miles, Huberman, dan Saldana, (2014) yaitu melalui Langkah-langkah mereduksi data, menyajikan data, dan menarik kesimpulan. Hasil penelitian menunjukkan bahwa 1) SMA Negeri 2 Banguntapan Bantul melakukan pengembangan program kewirausahaan yang mengacu pada visi dan misi sekolah; 2) Penanaman sikap berwirausaha dilakukan dalam beberapa tahap koordinasi persiapan dan perencanaan, pengembangan kewirausahaan pada Kurikulum, sosialisasi pada warga sekolah, motivasi oleh praktisi dan kunjungan ke DUDI, IHT kewirausahaan; 3) Implementasi pengembangan program kewirausahaan dilakukan dengan melakukan integrasi mata pelajaran maupun dalam kegiatan ekstrakurikuler; pembentukan Kelompok Usaha Siswa (KUS), dan dengan adanya Bazar.
\end{abstract}

Kata kunci: kewirausahaan, integrasi pembelajaran, SMA, Kelompok Usaha sekolah, DUDI

\begin{abstract}
The purpose of this study was to explore the process of implementing entrepreneurship programs through craft and entrepreneurship learning at SMA Negeri 2 Banguntapan Bantul. This research is a descriptive qualitative research. Data collection was carried out through interviews, observation, and document analysis. We conducted interviews with school principals, viceprincipals, teachers, students, and parents. We conducted data analysis referring to the writing of Entrepreneurship Education (Naswan Suharsono, Undiksha), namely through steps to reduce data, present data, and draw conclusions. The results showed that 1) SMA Negeri 2 Banguntapan Bantul developed entrepreneurship programs that refer to the school's vision and mission; 2) Cultivating an entrepreneurial attitude is carried out in several stages of coordination, preparation and planning, entrepreneurship development in the curriculum, outreach to school members, motivation by practitioners and visits to DUDI, entrepreneurial IHT; 3) The implementation of entrepreneurship program development is carried out by integrating subjects and extracurricular activities; the formation of the Student Business Group (KUS), and the existence of the Bazaar.
\end{abstract}

Keywords: entrepreneurship, learning integration, high school, school business group, DUDI

\section{PENDAHULUAN}

Kekhawatiran orangtua terhadap anaknya setelah menempuh pendidikan tingkat SMA meningkat, hal ini terjadi seiring bertambahnya jumlah pengangguran di dunia pada umumnya, Indonesia pada khususnya. Berbagai usaha telah dilakukan oleh orangtua, 
masyarakat, dan pemerintah dalam upaya mempersiapkan sumberdaya manusia untuk siap menghadapi tantangan di era gobalisasi di abad 21.

Indonesia sebagai negara besar dengan jumlah penduduk sekitar 267 jiwa di tahun 2020 (BPS Pusat, 2020) menjadi negara yang kuat apabila warga negaranya melakukan usaha wirausaha dalam kehidupan kesehariannya, selaian dapat menciptakan lapangan pekerjaan untuk diri sendiri juga dapat memberikan untuk orang lain, dengan kehadiran wirausaha negara tidak terbebani dengan membuka lapangan pekerjaan yang baru (Widiyarini, 2018).

Ada 8 negara termasuk Indonesia yang mengalami penurunan skor GEI terbesar dibandingkan tahun sebelumnya. Hasil pengukuran ini didasarkan pada 14 pilar yang dikelompokkan ke dalam 3 subindex yaitu sikap kewirausahaan, kemampuan kewirausahaan, dan gagasan kewirausahaan. Termasuk di antara pilar tersebut adalah menangkap peluang (Pillar 1), kemampuan memulai (Pillar 2), inovasi produk (Pillar 10), dan inovasi proses (Pillar 11). Pada 2018, Indonesia berada di peringkat 94 yang masih di bawah beberapa negara ASEAN lainnya. (Ács et al., 2018)

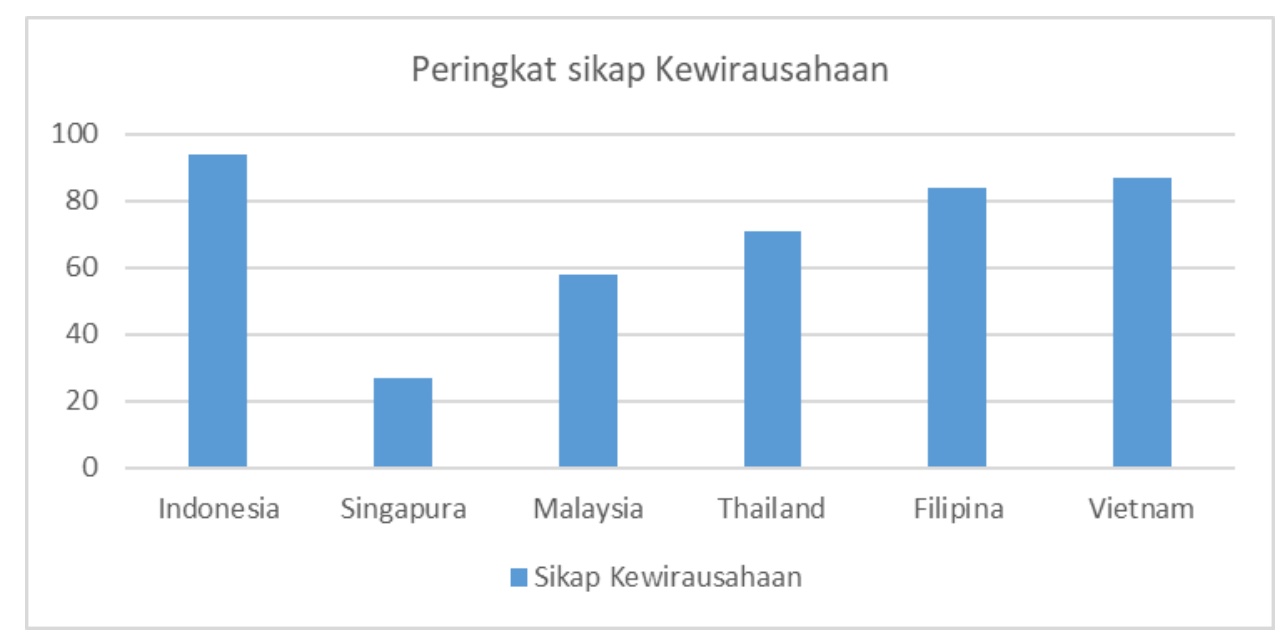

\section{Gambar 1. Sikap gagasan dan kemampuan wirausaha (sumber: Acs et al 2018)}

Disisi lain yang menambah ironis, bahwa tantangan yang dihadapi bangsa Indonesia terutama semakin meningkatnya jumlah penduduk usia produktif yang akan mencapai puncaknya pada tahun 2020-2035 pada saat angkanya mencapai $70 \%$, artinya bahwa anak usia 19-23 tahun (lulusan SMA atau SMK) tidak semua dapat melanjutkan ke perguruan tinggi, sebanyak 70,1\% tidak dapat melanjutkan, sementara sebagian mereka belum memiliki keterampilan untuk terjuan di masyarakat, dikarenakan mereka belum memiliki sikap, pengetahuan, keterampilan tentang wirausaha dengan baik. 


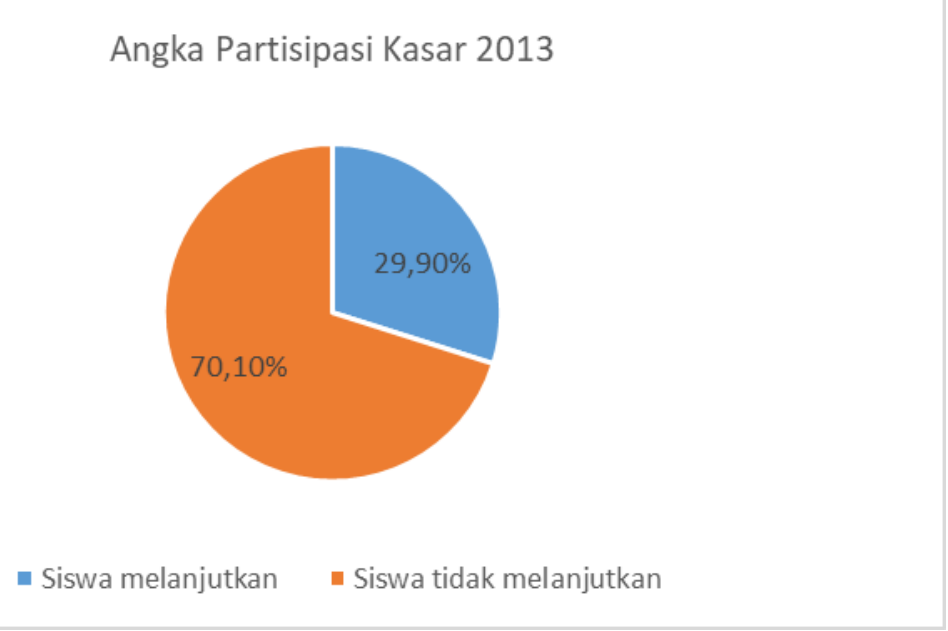

\subsection{Angka Partisipasi Kasar (sumber: BPS 2013)}

Pemerintah telah berupaya untuk meningkatkan mutu sumberdaya manusia yang lebih kreatif dan produktif, Undang-undang Nomor 20 Tahun 2003 tentang Sistem Pendidikan Nasional disebutkan bahwa tujuan pendidikan adalah mempersiapkan insan Indonesia untuk memiliki kemampuan hidup sebagai pribadi dan warganegara yang produktif, kreatif, inovatif, dan afektif serta mampu berkontribusi pada kehidupan bermasyarakat, berbangsa, bernegara dan peradaban dunia. Pada jenjang pendidikan dasar dan menengah, Kemendikbud telah menjabarkannya melalu langkah strategis dalam implementasi Kurikulum 2013.

Tujuan Kurikulum 2013 akan lebih tercapai ketika peserta didik memiliki jiwa dan ketrampilan kewirausahaan, mereka akan menjadi warganegara yang produktif, kreatif dan inovatif yang dilandasi nilai-nilai karakter bangsa dan mampu berkontribusi pada kehidupan bermasyarakat. Rancangan Kurikulum 2013 merupakan implementasi kecakapan abad 21 atau diistilahkan dengan 4C (Critical Thinking, Creativity, Collaboration dan Communication). Integrasi capaian kemampuan tersebut dirumuskan terutama dalam mata pelajaran Prakarya dan kewirausahaan dalam Kurikulum 2013.

Struktur kurikulum 2013 SMA memuat mata pelajaran prakarya dan kewirausahaan yang memberikan pemahaman dasar tentang kemampuan berwirausaha kepada peserta didik. Melalui pembelajaran Prakarya dan Kewirausahaan peserta didik dapat mempelajari teori dan nilai-nilai kewirausahaan yang dapat diaplikasikan dalam kehidupan nyata melalui praktik, baik yang terintegrasi dalam mata pelajaran maupun yang dilaksanakan diluar mata pelajaran atau kegiatan ekstrakurikuler. Salah satu solusi untuk mengatasinya dengan menerapkan program Kewirausahaan di SMA yang diharapkan dapat mendorong 
peserta didik untuk menjadi kreatif dan mandiri, serta mulai tergerak dan berani membuka usaha sendiri.

Program kemandirian peserta didik salah satu harapan yang terdapat dalam program kewirausahaan, dengan menerapkan program kewirausahaan diharapkan dapat menciptakan calon-calon wirausaha yang tahan terhadap tantangan hidup di era globalisasi yang kian kompetitif saat ini. Tidak hanya berharap setelah lulus menjadi seorang pegawai atau karyawan, namun dapat menangkap peluang menjadi kesempatan membuka usaha atau lapangan pekerjaan sendiri. Program kewirausahaan dimaksudkan sebagai salah satu upaya memberi bekal kepada peserta didik agar mereka memahami konsep kewirausahaan, memiliki karakter berwirausaha, mampu memanfaatkan peluang, dan mendapatkan pengalaman langsung berwirausaha, serta terbentuknya lingkungan sekolah yang berwawasan kewirausahaan.

Pengembangan program wirausaha yang diterapkan di Sekolah Menengah Atas Negeri 2 Banguntapan Bantul diharapkan dapat dijadikan sebagai role model dan acuan bagi sekolah lainnya untuk mengembangkan program wirausaha di satuan pendidikan masing masing, khususnya di daerah Bantul. Sekolah Menengah Atas Negeri 2 Banguntapan telah melakukan terobosan pengembangan kewirausahaan yang sesuai dengan visi dan misi sekolah. Diharapkan dengan adanya mata pelajaran prakarya dan kewirausahaan bisa menumbuhkan minat siswa untuk memulai usaha yang sifatnya masih sederhana. Berdasarkan hasil pengamatan di atas, peneliti menganggap sangat penting untuk mengadakan penelitian tentang : "Implementasi program kewirausahaan melalui pembelajaran prakarya dan kewirausahaan di SMA Negeri 2 Banguntapan Bantul dengan tujuan untuk memperoleh informasi rinci dan analisa dari implementasi program kewirausahaan di SMA Negeri 2 Banguntapan melalui pelajaran prakarya dan kewirausahaan.

\section{Rumusan Masalah}

Bagaimana implementasi program kewirausahaan di SMA Negeri 2 Banguntapan melalui pelajaran Prakarya dan kewirausahaan?

\section{Tujuan Penelitian}

Memperoleh informasi rinci dan analisa dari implementasi program kewirausahaan di SMA Negeri 2 Banguntapan melalui pelajaran Prakarya dan kewirausahaan. 


\section{KAJIAN PUSTAKA}

\section{Implementasi}

Implementasi suatu kegiatan dilaksanakan setelah melalui tahap perencanaan dilanjutkan dengan pengorganisasian segala sumber daya yang dimiliki oleh suatu organisasi dengan matang baru dilaksanakan dalam suatu kegiatan nyata. Menurut Saure Dan Dislainer dalam Wanadiana (2010:137), Pengarahan merupakan petunjuk untuk melaksanakan sesuatu, atau perintah resmi seseorang pimpinan kepada bawahannya berupa petunjuk untuk melaksanakan sesuatu. Pengarahan terdiri dari beberapa kegiatan yakni pengarahan (commanding), bimbingan (directing), dan kumunikasi (communication). Sedangkan menurut Andri \& Endang, (2015: 47) menjelaskan kegitan pengarahan dilakukan memiliki fungsi pokok, antara lain: (1)mempengaruhi seseorang supaya bersedia menjadi pengikut. (2)menaklukkan daya tolak seseorang. (3)membuat seseorang atau orang-orang suka mengerjakan tugas dengan lebih baik. (4)mendapatkan, memelihara dan memupuk kesetiaan pada pimpinan, tugas dan organisasi tempat mereka bekerja. (5)menanamkan, memelihara dan memupuk rasa tanggung jawab seorang atau orang-orang terhadap Tuhannya, Negara dan masyarakat. Subryosubroto (2005:54) menambahkan kegiatan pengkoordinasian dapat dilakukan melalui berbagai cara: (1) menjalankan penjelasan singkat/ briefing, (2) melaksanakan rapat kerja, (3) mengarahkan petunjuk pelaksanaan dan petunjuk teknis, dan (4) memberikan balikan tentang hasil suatu kegiatan. Rangkaian proses manajemen, pelaksanaan (actuating) merupakan fungsi manajemen yang paling utama. Dalam fungsi perencanaan dan pengorganisasian lebih banyak berhubungan dengan aspek-aspek abstrak proses manajemen, sedangkan fungsi actuating justru lebih menekankan pada kegiatan yang berhubungan langsung dengan orang-orang dalam organisasi.

Menurut G.R Terry "....Actuating is getting all the members of the group to want to achieve and strive to achieve mutual objectives because the want to achieve them" G.R Terry (1997:4) mengemukakan bahwa actuating merupakan bertindak adalah membuat semua anggota kelompok ingin berprestasi dan berusaha mencapai tujuan bersama karena ingin mencapainya. Hal yang penting untuk diperhatikan dalam pelaksanan (actuating) ini adalah bahwa seorang termotivasi untuk mengerjakan sesuatu jika (1) merasa yakin akan mampu mengerjakan, (2) yakin bahwa pekerjaan tersebut memberikan manfaat bagi dirinya, (3) tidak sedang dibebani oleh problem pribadi atau tugas lain yang lebih penting atau mendesak, (4) tugas tersebut merupakan kepercayaan bagi yang bersangkutan dan (5) hubungan antar teman dalam organisasi tersebut harmonis. 


\section{Pendidikan Kewirausahaan}

Pemahaman tentang berwirausaha perlu didapatkan baik secara teori maupun praktek baik dari lingkungan keluarga maupun sekolah. Menurut Suherman (2010:10) pendidikan kewirausahaan merupakan proses penanaman kreatifitas dan inovasi dalam mengatasi masalah, hambatan berbagai resiko dan peluang untuk berhasil. Pendidikan kewirausahaan mengajarkan penanaman nilai-nilai kewirausahaan yang akan membentuk karakter dan perilaku untuk berwirausaha agar peserta didik dapat kreatif dan produktif, selain hal tersebut juga membekali dengan berbagai kompetensi kewirausahaan yang nantinya akan membawa manfaat besar bagi peserta didik. Pengembangan Pendidikan Kewirausahaan merupakan salah satu program Kementerian Pendidikan Nasional yang pada intinya adalah pengembangan metodologi pendidikan yang bertujuan untuk membangun manusia yang berjiwa aktif, kreatif, inovatif dan wirausaha. Program ini ditindaklanjuti dengan upaya mengintegrasikan kegiatan dalam pembelajaran, pendidikan karakter anak, pendidikan ekonomi kreatif, dan pendidikan kewirausahaan ke dalam isi kurikulum.

\section{Prakarya dan kewirausahaan}

Pembelajaran Prakarya dan Kewirausahaan merupakan salah satu mata pembelajaran yang bertujuan untuk memberikan bekal pemikiran, sikap, dan kebiasaan wirausaha kepada peserta didik, memberikan pengetahuan, keterampilan berwirausahaan, baik berupa barang maupun jasa kepada peserta didik" Wahyu (2016:16). Kementrian Pendidikan dan kebudayaan (2013) menyebutkan bahwa "prakarya adalah usaha untuk memperoleh keahlian cekat, cepat dan tepat dengan pengolahan, rekayasa, kerajianan dan budidaya memanfaatkan bahan, alat, teknik, dan ilmu pengetahuan”. Ruang Lingkup mata pelajaran Prakarya dan Kewirausahaan pada mata pelajaran prakarya dan kewirausahaan terdapat empat 4 (konsentrasi) yaitu pengolahan, rekayasa, kerajianan dan budidaya.

Penjelasan ruang lingkup dari setiap standar tersebut adalah sebagai berikut :1)Kerajinan dikaitkan dengan nilai pendidikan diwujudkan dalam prosedur pembuatan. Prosedur memproduksi dilalui dengan berbagai tahapan dan beberapa langkah yang dilakukan oleh beberapa orang. Kinerja ini menumbuhkan wawasan, toleransi sosial serta social corporateness memulai pemahaman karya orang lain. 2)Rekayasa diartikan usaha memecahkan permasalahan kehidupan sehari-hari dengan berpikir rasional dan kritis sehingga menemukan kerangka kerja yang efektif dan efisien. Prinsip rekayasa adalah mendaur ulang sistem, bahan, dan ide yang disesuaikan dengan perkembangan zaman (teknologi) terbarukan. Oleh karenanya, rekayasa harus seimbang dan selaras dengan 
kondisi dan potensi daerah setempat menuju karya yang mempunyai nilai jual yang tinggi.3) Budidaya berpangkal pada cultivation, yaitu suatu kerja yang berusaha untuk menambah, menumbuhkan, dan mewujudkan benda ataupun makhluk agar lebih besar (tumbuh), dan berkembang (banyak). Kinerja ini membutuhkan perasaan seolah dirinya (pembudidaya) hidup, tumbuh dan berkembang. 4)pengolahan artinya membuat, menciptakan bahan dasar menjadi benda produk jadi agar dapat dimanfaatkan secara maslahat. Pada prinsipnya, kerja pengolahan adalah mengubah benda mentah menjadi produk matang dengan mencampur, atau memodifikasi bahan tersebut.

\section{Sekolah Program Kewirausahaan}

Program kewirausahaan bertujuan untuk membentuk manusia secara utuh (holistik), sebagai insan yang memiliki karakter, pemahaman dan ketrampilan sebagai wirausaha. Pada dasarnya, program kewirausahaan dapat diimplementasikan secara terpadu dengan kegiatan-kegiatan pendidikan di sekolah. Pelaksanaan pendidikan kewirausahaan dilakukan oleh kepala sekolah, guru, tenaga kependidikan, peserta didik secara bersamasama sebagai suatu komunitas pendidikan. Program kewirausahaan diterapkan ke dalam kurikulum dengan cara mengidentifikasi jenis-jenis kegiatan di sekolah yang dapat merealisasikan pendidikan kewirausahaan dan direalisasikan peserta didik dalam kehidupan sehari-hari. Dalam hal ini, program pendidikan kewirausahaan di sekolah dapat diinternalisasikan melalui berbagai aspek: 1) Pendidikan kewirausahaan terintegrasi di dalam proses pembelajaran adalah penginternalisasian nilai-nilai kewirausahaan ke dalam pembelajaran sehingga hasilnya diperolehnya kesadaran akan pentingnya nilai-nilai, terbentuknya karakter wirausaha dan pembiasaan nilai-nilai kewirausahaan ke dalam tingkah laku peserta didik sehari-hari, melalui proses pembelajaran baik yang berlangsung di dalam maupun di luar kelas pada semua mata pelajaran. Pada dasarnya kegiatan pembelajaran, selain untuk menjadikan peserta didik menguasai kompetensi (materi) yang ditargetkan, juga dirancang dan dilakukan untuk menjadikan peserta didik mengenal, menyadari, dan menginternalisasi nilai-nilai kewirausahaan dan menjadikannya perilaku dalam kehidupan. Langkah ini dilakukan dengan cara mengintegrasikan nilai-nilai kewirausahaan ke dalam pembelajaran di seluruh mata pelajaran yang ada di sekolah, pada saat menyampaikan materi, melalui metode pembelajaran maupun melalui sistem penilaian. Dalam pengintegrasian nilai-nilai kewirausahaan ada banyak nilai yang dapat ditanamkan pada peserta didik. Nilai-nilai kewirausahaan tersebut harus ditanamkan dengan intensitas yang sama pada semua mata pelajara. Selanjutnya nilai-nilai pokok 
tersebut diintegrasikan pada semua mata pelajaran. Nilai-nilai pokok kewirausahaan yang diintegrasikan ke semua mata pelajaran pada langkah awal ada 6 (enam) nilai pokok yaitu: mandiri, kreatif pengambil resiko, kepemimpinan, orientasi pada tindakan dan kerja keras. 2) Kegiatan Ekstra Kurikuler adalah kegiatan pendidikan di luar mata pelajaran dan pelayanan konseling untuk membantu pengembangan peserta didik sesuai dengan kebutuhan, potensi, bakat, dan minat mereka melalui kegiatan yang secara khusus diselenggarakan oleh pendidik dan atau tenaga kependidikan yang berkemampuan dan berkewenangan di sekolah. Visi kegiatan ekstra kurikuler adalah berkembangnya potensi, bakat dan minat secara optimal, serta tumbuhnya kemandirian dan kebahagiaan peserta didik yang berguna untuk diri sendiri, keluarga dan masyarakat. Misi ekstra kurikuler adalah (1) menyediakan sejumlah kegiatan yang dapat dipilih oleh peserta didik sesuai dengan kebutuhan, potensi, bakat, dan minat mereka; (2) menyelenggarakan kegiatan yang memberikan kesempatan peserta didik mengespresikan diri secara bebas melalui kegiatan mandiri dan atau kelompok. 3) Pengembangan diri merupakan kegiatan pendidikan di luar mata pelajaran sebagai bagian integral dari kurikulum sekolah. Kegiatan pengembangan diri merupakan upaya pembentukan karakter termasuk karakter wirausaha dan kepribadian peserta didik yang dilakukan melalui kegiatan pelayanan konseling berkenaan dengan masalah pribadi dan kehidupan sosial, kegiatan belajar, dan pengembangan karir, serta kegiatan ekstra kurikuler. Pengembangan diri yang dilakukan dalam bentuk kegiatan pengembangan kompetensi dan kebiasaan dalam kehidupan sehari-hari peserta didik. Pengembangan diri bertujuan memberikan kesempatan kepada peserta didik untuk mengembangkan dan mengekspresikan diri sesuai dengan kebutuhan, potensi, bakat, minat, kondisi dan perkembangan peserta didik, dengan memperhatikan kondisi sekolah. Pengembangan diri secara khusus bertujuan menunjang pendidikan peserta didik dalam mengembangkan: bakat, minat, kreativitas, kompetensi, dan kebiasaan dalam kehidupan, kemampuan kehidupan keagamaan, kemampuan sosial, kemampuan belajar, wawasan dan perencanaan karir, kemampuan pemecahan masalah, dan kemandirian. Pengembangan diri meliputi kegiatan terprogram dan tidak terprogram. Kegiatan terprogram direncanakan secara khusus dan diikuti oleh peserta didik sesuai dengan kebutuhan dan kondisi pribadinya. Dalam program pengembangan diri, perencanaan dan pelaksanaan pendidikan kewirausahaan dapat dilakukan melalui pengintegrasian kedalam kegiatan sehari-hari sekolah 'business day’ (bazar, karya peserta didik). 


\section{METODE PENELITIAN}

Penelitian ini menggunakan metode penelitian kualitatif di mana penelitian kualitatif sebagai metode ilmah yang yang bersifat deskriptif digunakan dan dilaksanakan oleh sekolompok peneliti dalam bidang ilmu sosial, termasuk juga ilmu pendidikan. Menurut Melong (2012:4) pendekatan kualitatif ini adalah metode yang digunakan untuk menganalisa data dengan mendeskripsikan data melalui kata-kata yang digunakan untuk menafsirkan dan menginterpretasikan data dari hasil kata-kata atau lisan dari orang tertentu dan perilaku yang diamati, Suharsimi Arikunto,(2002:23). Metode ini disebut juga sebagai metode aristik, karena proses penelitian lebih bersifat seni (kurang terpola), dan disebut sebagai metode interpretive karena data hasil penelitian lebih berkenaan dengan interpretasi terhadap data yang ditemukan di lapangan. Penelitian ini menggunakan pendekatan penelitian kualitatif, karena pada penelitian kualitatif menggunakan latar belakang alamiah apa adanya, tanpa dimanipulasi sehingga tidak mementingkan hasil yang diperoleh tetapi proses pelaksanaan. Penelitian kualitatif merupakan penelitian bertujuan untuk memahami fenomena tentang apa yang dialami oleh subjek penelitian perilaku, persepsi, motivasi, tindakan secara holistik dan dengan cara deskripsi, pada suatu konteks khusus yang alamiah memanfaatkan cara alamiah Meleong (2011:6). Penelitian ini ditekankan pada implementasi program kewirausahaan melalui pelajaran Prakarya dan kewirausahaan di SMA Negeri 2 Banguntapan.

\section{Partisipan}

Subjek penelitian adalah seseorang atau sesuatu yang berkaitan penelitian ingin diperoleh keterangannya yang mendukung penelitian, Tatang (1995: 92). Partisipasi dalam penelitian ini yaitu kepala sekolah, guru, dan siswa. Adapun rincian dari subjek penelitian ini adalah kepala sekola, wakil kepala sekolah urusan kurikulum, guru pengampu mata pelajaran prakarya dan kewirausahaan dan siswa yang mengikuti program kewirausahaan di integrasikan dalam mata pelajaran prakarya dan kewirausahaan yang berbeda jenis usahanya. Objek penelitian ini adalah implementasi sekolah kewirausahaan di SMA Negeri 2 Banguntapan melalui pelajaran Prakarya dan kewirausahaan.

Informan penelitian ini adalah sebagai berikut:

a) Kepala SMA Negeri 2 Banguntapan yaitu untuk mendapatkan data tentang implementasi program kewirausahaan melalui pembelajaran prakarya dan kewirausahaan di SMA Negeri 2 Banguntapan. 
b) Tenaga kependidikan di Kepala SMA Negeri 2 Banguntapan untuk mendapatkan informasi tentang implementasi program kewirausahaan melalui pembelajaran prakarya dan kewirausahaan di SMA Negeri 2 Banguntapan.

c) Peserta didik untuk mendapatkan informasi tentang implementasi program kewirausahaan melalui pembelajaran prakarya dan kewirausahaan di SMA Negeri 2 Banguntapan.

\section{Proses pengumpulan data.}

Dalam penelitian ini ada dua jenis data yang dikumpulkan yaitu data primer dan data sekunder. Data primer yaitu data yang diamati dari sumbernya langsung, diamati dan dicatat untuk pertama kalinya, Margono (2000:87). Adapun data primer dalam penelitian ini diperoleh oleh peneliti dari hasil wawancara dengan kepala sekolah, waka kurikulum, guru, dan beberapa siswa di SMA Negeri 2 Banguntapan.

Data sekunder adalah data yang bukan diusahakan sendiri pengumpulannya oleh peneliti. Data sekunder berasal dari tangan kedua, ketiga, dan seterusnya, artinya melewati satu atau lebih dari pihak yang bukan peneliti sendiri. Karena itu perlu adanya pemerikasaan ketelitian, Marzuki (2000:55). Data sekunder juga sangat penting karena peneliti juga membutuhkan banyak informasi yang bermanfaat dan berpotensi untuk mendapatkan hasil yang maksimal. Data sekunder juga dapat berupa buku, artikel, dan berbagai literature yang relevan dan berhubungan dengan pembahasan penelitian.

Cara Pengumpulan Data Dalam penelitian kualitatif, yang menjadi instrumen utama adalah peneliti sendiri menetapkan fokus penelitian, memilih informan sebagai sumber data, melakukan pengumpulan data, menilai kualitas data, analisis data, menafsirkan data dan membuat kesimpulan atas temuanya, Sugiyono (2017:300).

Mengumpulkan data merupakan langkah yang tidak dapat dihindari dalam kegiatan penelitian dengan pendekatan apapun, termasuk penelitian kualitatif. Untuk lebih jelasnya, dapat diuraikan sebagai berikut:

1. Wawancara

Pada saat pengumpulan data kualitatif, selain menggunakan teknik observasi partisipan, peneliti juga dapat menggunakan teknik wawancara. Wawancara merupakan sebuah percakapan antara dua orang atau lebih, yang pertanyaannya diajukan oleh peneliti kepada subjek atau sekelompok subjek penelitian untuk dijawab, Sudarwan, Danim (2002:130). 
Pada penelitian ini, wawancara dilakukan dengan siswa, guru mata pelajaran, waka kurikulum dan kepala sekolah di SMA Negeri 2 Banguntapan. Wawancara dilakukan secara personal, dengan mempersiapkan pedoman wawancara terlebih dahulu. Pedoman wawancara tersebut berisi tentang implementasi program kewirausahaan melalui pembelajaran prakarya dan kewirausahaan di SMA Negeri 2 Banguntapan.

Setelah dilakukan wawancara, peneliti melakukan triangulasi dengan membandingkan dan mengecek kepercayaan suatu informasi yang diperoleh sumber lain yang berbeda dalam penelitian kualitatif. Untuk mencapai kepercayaan itu adalah dengan membandingkan hasil wawancara antara guru, siswa, waka kurikulum dan kepala sekolah tentang implementasi program kewirausahaan melalui pembelajaran prakarya dan kewirausahaan di SMA Negeri 2 Banguntapan.

\section{Observasi}

Observasi adalah suatu kegiatan yang dilakukan oleh peneliti untuk mendapatkan informasi dengan cara mengamati. Observasi dapat ditujukan kepada siswa secara perorangan atau kelompok, Wahidmurni, (2010:79) Observasi sebagai teknik pengumpulan data yaitu mempunyai ciri yang spesifik jika dibandingkan dengan teknik yang lain, seperti wawancara dan kuesioner. Sutrisno Hadi mengemukakan bahwa, observasi merupakan suatu proses yang komplek, karena suatu proses yang tersusun dari berbagai proses biologis dan psikologis. Dua diantara yang terpenting adalah proses pengamatan dan ingatan. Dalam penelitian ini, observasi lapangan dilakukan oleh peneliti dengan cara melihat langsung ke lokasi yaitu di SMA Negeri 2 Banguntapan.

Dalam penelitian ini metode dokumentasi digunakan untuk tujuan mengumpulkan data yang berhubungan; profil sekolah, struktur organisasi, visi dan misi sekolah, kondisi sarana dan prasarana sekolah, data nilai siswa yang bersangkutan, keadaan dan jumlah siswa serta guru. verifications atau sering dikenal dengan penarikan kesimpulan dan verifikasi, Miles and Hubermaqn (1984:337).

\section{Proses analisis data}

\section{Reduksi Data}

Data yang diperoleh dari lapangan jumlahnya cukup banyak, maka untuk itu perlu dicatat dan diteliti secara rinci, dan dibutuhkan analisis data melalui reduksi data. Mereduksi data berarti merangkum, memilih hal-hal yang pokok, memfokuskan pada hal hal yang penting Miles and Huberman(1984:338). Dengan begitu, maka data yang nantinya akan dipaparkan dalam penelitian ini akan lebih jelas dan mudah dipahami karena 
hanya merupakan data yang memberikan informasi penting dan memberikan gambaran secara menyeluruh.

\section{Penyajian Data}

Setelah data direduksi, maka langkah selanjutnya adalah mendisplaykan data. Dalam penelitian ini penyajian data akan disajikan dengan uraian teks yang bersifat narasi. Tujuan dalam pendisplayan data ini adalah agar hasil penelitian ini mudah untuk difahami.

\section{Verifikasi}

Langkah ketiga dalam analisis data adalah verifikasi atau penarikan kesimpulan dan verifikasi. Dengan langkah ini maka diharapkan dapat menjawab rumusan masalah yang telah ditetapkan sehingga menjadi suatu masalah yang sudah jelas dan mungkin dapat menemukan temuan baru yang sebelumnya belum pernah ada. Menurut Bogdan dan Biklen, seperti yang dikutip Lexy Moleong, analisis data kualitatif adalah upaya yang dilakukan dengan data, memilah-milah menjadi satuan yang bisa dikelola, mensistensikannya, mencari dan menemukan pola, menemukan apa yang penting dan apa yang dipelajari, dan memutuskan apa yang dapat diceritakan oleh orang lain, Moleong (2009:248)

\section{Trianggulasi Data}

Dalam penelitian yang terkait dengan implementasi program kewirausahaan melalui pembelajaran prakarya dan kewirausahaan di SMA Negeri 2 Banguntapan, untuk mendapatkan tingkat kepercayaan atau kredibiltas yang tinggi sesuai dengan fakta di lapangan, maka peneliti harus memastikan apakah interpretasi dan temuan penelitian akurat. Dalam penelitian ini, peneliti menggunakan teknik trianggulasi. Trianggulasi adalah teknik pemeriksaan keabsahan data yang memanfaatkan sesuatu yang lain diluar data itu untuk keperluan pengecekan atau pembanding terhadap data. Trianggulasi yaitu metode yang dilakukan dengan cara membandingkan informasi atau data dengan cara yang berbeda. Dalam konteks ini, trianggulasi yang dilakukan, terdiri dari empat, yaitu a) Trinaggulasi data (data triangguation) atau triangulasi sumber adalah penelitian dengan menggunakan berbagai sumber data yang berbeda untuk mengumpulkan data yang sejenis; b) Trianggulasi peneliti (investigator trianggulation) adalah hasil peneliti baik dan maupun simpulan mengenai bagian tertentu atau keseluruhannya bisa diuji validitasnya dari beberapa peneliti; c) Trianggulasi metodologis (methodological trianggulation) jenis trianggulasi bisa dilakukan oleh seorang peneliti dengan mengumpulkan data sejenis tetapi dengan menggunakan teknik atau metode pengumpulan data yang berbeda; d) Trianggulasi 
teoritis (theoretical trianggulation) trianggulasi ini dilakukan oleh peneliti dengan menggunakan perspektif lebih dari satu teori dalam membahas permasalahan yang dikaji. Trianggulasi yang digunakan dalam penelitian ini adalah triangulasi sumber yaitu menggali kebenaran informasi tertentu melalui berbagai metode dan sumber perolehan data itu. Dalam hal ini peneliti membandingkan hasil wawancara yang diperoleh dari siswa, guru, waka kurikulum dan kepala sekolah yang terkait dengan implementasi program kewirausahaan melalui pembelajaran prakarya dan kewirausahaan di SMA Negeri 2 Banguntapan. Dari metode yang berbeda, maka diperoleh data yang berbeda pula dan akhirnya akan diperoleh dengan keluasan pengetahuan untuk memperoleh suatu kebenaran yang handal. Metode yang dipakai, yaitu: (1)Membandingkan data hasil pengamatan dengan hasil wawancara. (2)Membandingkan perkataan orang didepan umum dengan perkataan secara pribadi. (3) Membandingkan apa yang dikatakan orang tentang situasi penelitian dengan apa yang dikatakan orang disepanjang waktu. (4)Membandingkan keadaan dan perspektif secara seorang dengan berbagai pendapat dan pandangan orang seperti rakyat biasa, orang berpendidikan menengah atau tinggi, orang berada dan pemerintah. (5)Membandingkan hasil wawancara dengan isi suatu dokumen yang berkaitan.

\section{HASIL DAN PEMBAHASAN}

Berdasarkan data yang dapat dikumpulkan, diketahui bahwa Pelaksanaan program kewirausahaan dimulai tanggal 4 Mei 2018 hingga sekarang. Program kewirausahaan ini di terapkan hanya untuk kelas $\mathrm{X}$ dengan tujuan untuk memberikan informasi sejak dini terkait kewirausahaan dan karena di kelas $\mathrm{X}$ belum begitu banyak tugas dalam kegiatan belajar mengajar belum begitu berat di bandingkan kelas XI dan XII. Program integrasi kewirausahaan masuk dalam pembelajaran mengacu pada panduan RPP sesuai dengan kurikulum 2013. Siswa yang dibekali dan diberi pelatihan skill dan keterampilan serta pengajaran tentang prakarya dan kewirausahaan, tidak hanya mendapatkan teori di dalam kelas namun juga mempraktikkannya langsung dilapangan, hal ini dimaksudkan untuk mengukur seberapa besar penerapan teori tentang prakarya dan kewirausahaan siswa di dalam lapangan (Elliott et al., 2020). Di SMA Negeri 2 Banguntapan siswanya mendapatkan tugas praktik prakarya dan kewirausahaan dari gurunya untuk membuka peluang bagi mereka dalam mengembangkan ide dan kreatifitas dibidang wirausaha oleh karena itu diarahkan siswa untuk berlatih membuat bisnis yang skala kecil-kecilan dapat berupa membuat barang kerajianan, budidaya hewan dan tumbuhan yang layak jual, 
pengolahan barang sisa proses produksi, dan sebagainya sesuai dengan bakat minat peserta didik yang sekiranya laku di pasar yang diminati konsumen.

Rangkaian kegiatan adalah sebagai berikut:1) melaksanakan koordinasi persiapan dan perencanaan, 2) pengembangan kewirausahaan kurikulum, 3) sosialisasi kepada warga sekolah, 4) motivasi dari praktisi wirausahawan, 5)In Haouse Training (IHT) kewirausahaan, 6) Implementasi kewirausahaan melalui kelompok usaha siswa, 7) implementasi kewirausahaan pameran karya siswa melalui bazar, dan 8) penyusunan laporan dan dokumentasi.

\section{1) Proses keordinasi persiapan dan perencanaan;}

Penelitian ini menganalisis bagaimana implementasi program pengembangan kewirausahaan bagi pelaku usaha sosial dalam meningkatkan pengetahuan kewirausahaan, kemampuan kewirausahaan, dan mental kewirausahaan sehingga terciptanya pelaku usaha yang kompetitif dan berdaya saing tinggi baik dari segi penciptaan produk ataupun jasa, maupun keahlian di bidang teknis dan lunak. Secara menyeluruh dapat disimpulkan bahwa program pengembangan kewirausahaan berdampak positif terhadap penciptaan pelaku usaha yang kompetitif.

Jika diterapkan dalam kewirausahaan sosial, maka tujuan akhirnya adalah menghasilkan produk atau jasa yang berdampak langsung terhadap perubahan sosial di lingkungan dimana dia tinggal. Pelaku usaha baik konvensional maupun sosial dapat bersaing dalam kompetisi global dikarenakan pengetahuan dan pengalaman kewirausahaannya.

2) Tahap-tahap kegiatan pengembangan program kewirausahaan

a. Melaksanakan keordinasi persiapan dan perencanaan.

Dalam mengawali kegiatan program kewirausahaan yang pertama adalah tahap persiapan yaitu dengan melakukan kegiatan sebelum memulai mengumpulkan datadata yang dibutuhkan untuk memenuhi sebelum kegiatan dilaksanakan. Selanjutnya menyusun rangkaian atau kerangka kegiatan yang akan dilakukan dengan tujuan agar waktu dan kegiatan yang akan dilakukan bisa efektif, efisien sesuai yang ditentukan. Adapun susunan dari tahapan yang dilakukan meliputi : 1) Studi pustaka dari berbagai sumber yang berhubungan dengan program kewirausahaan, 2) Menentukan data apa saja yang diperlukan untuk mendukung proses program kewirausahaan, 3) Mempersiapkan semua persyaratan administrasi dan teknis termasuk penanggungjawab yang akan melaksanakan program kewirausahaan. Selain hal 
tersebut juga mempersiapkan terkait dengan perencanaan. Pengertian perencanaan adalah suatu proses menentukan apa yang ingin dicapai di masa yang akan datang serta menetapkan tahapan-tahapan yang dibutuhkan untuk mencapainya, Rustiadi (2008:339). Dalam perencanaan akan terdapat aktivitas pengujian beberapa arah pencapaian, mengkaji ketidakpastian, menentukan arah pencapaian, serta menentukan langkah untuk mencapainya termasuk merencanakan sesuai rencana awal dan menentukan alternatifnya. Perencanaan merupakan salah satu fungsi manajemen yang paling penting di mana di dalamnya terdapat aktivitas mendefinisikan tujuan organisasi, membuat strategi, serta mengembangkan rencana kerja organisasi. Perencanaan adalah tahap awal dalam kegiatan suatu organisasi terkait dengan pencapaian tujuan organisasi tersebut.

kepala sekolah melakukan koordinasi dengan sumber daya yang dimiliki sekolah dari wakil kepala bagian kurikulum, kesiswaan, saranaprasarana dan humas juga dengan melibatkan wali kelas kelas $\mathrm{x}$ dengan guru pengampu mata pelajaran prakarya dan kewirausahaan. selanjutnya membentuk suatu Tim yang mengelolaan program kewirausahaan di SMA Negeri 2 Banguntapan. Bagaimana untuk memberikan pemahaman yang sama terhadap konsep dan pemahaman tentang program kewirausahaan melalui pembelajaran prakarya dan kewirausahaan yang akan dilaksanakan. Kelengkapan administrasi untuk menunjang program kewirausahaan, mempersiapkan data siswa yang akan mengikuti program kewirausahaan.

b. Pengembangan kewirausahaan kurikulum

Pendidikan kewirausahaan terintegrasi di dalam proses kurikulum adalah penginternalisasian nilai-nilai kewirausahaan ke dalam pembelajaran sehingga hasilnya diperolehnya kesadaran akan pentingnya nilai-nilai, terbentuknya karakter wirausaha dan pembiasaan nilai-nilai kewirausahaan ke dalam tingkah laku peserta didik sehari-hari melalui proses pembelajaran baik yang berlangsung di dalam maupun di luar kelas pada semua mata pelajaran. Pada dasarnya kegiatan pembelajaran, selain untuk menjadikan peserta didik menguasai kompetensi (materi) yang ditargetkan, juga dirancang dan dilakukan untuk menjadikan peserta didik mengenal, menyadari/peduli, dan menginternalisasi nilai-nilai kewirausahaan dan menjadikannya perilaku. Langkah ini dilakukan dengan cara mengintegrasikan nilai-nilai kewirausahaan ke dalam pembelajaran di seluruh mata pelajaran yang ada di sekolah. Langkah pengintegrasian ini bisa dilakukan pada saat menyampaikan materi, melalui metode pembelajaran maupun melalui sistem penilaian. 
Dalam pengintegrasian nilai-nilai kewirausahaan ada banyak nilai yang dapat ditanamkan pada peserta didik. Apabila semua nilai-nilai kewirausahaan tersebut harus ditanamkan dengan intensitas yang sama pada semua mata pelajaran, maka penanaman nilai tersebut menjadi sangat berat. Oleh karena itu penanaman nilai nilai kewirausahaan dilakukan secara bertahap dengan cara memilih sejumlah nilai pokok sebagai pangkal tolak bagi penanaman nilai-nilai lainnya. Selanjutnya nilai-nilai pokok tersebut diintegrasikan pada semua mata pelajaran.

Integrasi pendidikan kewirausahaan di dalam mata pelajaran dilaksanakan mulai dari tahap perencanaan, pelaksanaan, dan evaluasi pembelajaran pada semua mata pelajaran. Pada tahap perencanaan, silabus dan RPP dirancang agar muatan maupun kegiatan pembelajarannya memfasilitasi untuk mengintegrasikan nilai-nilai kewirausahaan. Cara menyusun silabus yang terintegrsi nilai-nilai kewirausahaan dilakukan dengan mengadaptasi silabus yang telah ada dengan menambahkan satu kolom dalam silabus untuk mewadahi nilai-nilai kewirausahaan yang akan diintegrasikan. Sedangkan cara menyususn RPP yang terintegrasi dengan nilai-nilai kewirausahaan dilakukan dengan cara mengadaptasi RPP yang sudah ada dengan menambahkan pana materi, langkah-langkah pembelajaran atau penilaian dengan nilai-nilai kewirausahaan.

Prinsip pembelajaran yang digunakan dalam pengembangan pendidikan kewirausahaan mengusahakan agar peserta didik mengenal dan menerima nilai-nilai kewirausahaan sebagai milik mereka dan bertanggung jawab atas keputusan yang diambilnya melalui tahapan mengenal pilihan, menilai pilihan, menentukan pendirian, dan selanjutnya menjadikan suatu nilai sesuai dengan keyakinan diri. Dengan prinsip ini, peserta didik belajar melalui proses berpikir, bersikap, dan berbuat. Ketiga proses ini dimaksudkan untuk mengembangkan kemampuan peserta didik dalam melakukan kegiatan yang terkait dengan nilai-nilai kewirausahaan. Pengintegrasian nilai-nilai kewirausahaan dalam silabus dan RPP dapat dilakukan melalui langkah-langkah berikut: 1) mengkaji SK dan KD untuk menentukan apakah nilai-nilai kewirausahaan sudah tercakup didalamnya. 2)mencantumkan nilai-nilai kewirausahaan yang sudah tercantum di dalam SKdan KD kedalam silabus. 3)mengembangkan langkah pembelajaran peserta didik aktif yang memungkinkan peserta didik memiliki kesempatan melakukan integrasi nilai dan menunjukkannya dalam perilaku. 4)memasukan langkah pembelajaran aktif yang terintegrasi nilai-nilai kewirausahaan ke dalam RPP. Pengintegrasian nilai-nilai kewirausahaan hendaknya memperhatikan 
potensi lokal daerah masing-masing, sesuai dengan lokasi/tempat siswa tinggal. Pertimbangan lain adalah heterogenitas latar belakang siswa, seperti kehidupan keluarga, sekolah, masyarakat, dan usia tingkat perkembangan siswa, yang pada gilirannya siswa akan memiliki jiwa berwirausaha dan memiliki kesadaran tinggi untuk mengaktualisasikan potensinya secara cerdas dalam kehidupan bermasayarakat.

c. Motivasi dari wirausahawan

Motivasi merupakan dorongan, minat yang terdapat dalam diri seseorang dalam mencapai harapan dan cita-cita yang diinginkan. motivasi merupakan suatu potensial terdapat dalam diri manusia dapat di tumbuhkembangkan baik diri sendiri maupun orang lain yang berkisar imbalan yang berbentuk uang maupun lainnya, winardi (2016:6)Orang yang memiliki motivasi akan melakukan mewujudkan harapannya dengan penuh semangat tidak mengenal hambatan dan kendala yang dihadapi. Wirausawan (entrepreneur) merupakan orang yag kegiatan keseharian memiliki kecerdasan memahami produk baru, cara membuatnya, mengatur operasional dalam menciptakan produk serta memasarkan produk konsumen dan memanajemen keuangannya.

Pemberian motivasi dari para praktisi atau wirausahawan diharapkan akan menerima informasi yang nyata tentang pengelolaan usaha baik keunggulan dan kelemahan yang dihadapi pelaku usaha, selain hal tersebut diharapkan akan menumbuhkan minat berwirausaha bagi peserta didik ditandai dengan adanya sikap dan wawasan kewirausahaan bagaimana seorang mumualai usaha, melakukannya dengan memualai dari nol, suka dukanya dalam menjalani mengelola usaha, pengalaman yang sangat mengesankan. Dengan pemberian motivasi peserta didik yang berminat dalam wirausaha akan tertarik dengan pengetahuan atau ilmu yang berhubungan dengan minatnya tersebut. Semakin besar minat siswa untuk tertarik kepada bidang kewirausahaan, maka akan besar pula usaha dan keinginan siswa untuk mewujudkannya keinginanya dalam melakasanakan wirausaha. Motivasi memiliki beberapa fungsi yang sangat membantu wirausaha pemula untuk mengawali kegiatan wirausaha, maka beberapa fungsinya diantaranya sebagai berikut :1)menentukan arah langkah dapat menuntun seseorang dalam menentukan langkah dalam memualai usaha, motivasi inilah yang akan menggerakkan siswa-siswa untuk selalu melakukan hal-hal terbaik dalam memualai usaha. Sehingga, motivasi juga dapat menentukan kesuksesan dalam memulai usaha. 2)menentukan keputusan tindakan saat menjalani wirausaha, tentu akan banyak tindakan-tindakan yang diambil, baik yang beresiko 
kecil hingga besar. Tujuan dan motivasi itu sendiri adalah untuk menentukan setiap tindakan yang diambil. Apakah suatu keputusan dalam mengambil tindakan sudah tepat sesuai kondisi? Bagaimana implikasi dan resiko ke depannya? Itu semua tergantung keputusan setelah menerima motivasi. 3)menyeleksi Perbuatan dengan motivasi dari orang yang sudah berpengalaman maka siswa yang akan memulai usaha dapat menentukan berbagai perbuatan yang menentukan skala prioritas. Artinya, siswa akan mampu menentukan perbuatan yang memberikan hasil baik ke depannya.

d. Kunjungan ke dunia usaha dan industri (DU/DI)

Kegiatan kunjungan ke dunia usaha dan industri diharapkan agar siswa mengenal situasi dan kondisi terbaru dunia kerja, apa yang perlu dipersiapkan dan direncanakan sejak sekarang. Ada beberapa kemajuan sebagai bentuk kedinamisan dalam hidup ada banyak perubahan yang saat ini dibutuhkan. Dengan kunjungan ini siswa dapat menambah wawasan tentang ketercapaian pembelajaran apa yang didapatkan di bangku sekolah dan di praktekkan di lapangan sehingga mempunyai kompetensi yang dibutuhkan. Selain hal tersebut juga mempunyai manfaat untuk memperluas wawasan teori siswa terkait dengan cara pengelolaan usaha yang tepat sehingga meminimkan kesalahan dalam pengelolaan usaha, apa yang dibutuhkan oleh pasar, kwalitas barang dan lain sebagainya. Disamping hal tersebut dalam kunjungan ke dunia usaha dan dunia industri membentuk sikap siswa mengenal budaya industri, disiplin dalam bekerja, memberikan pengetahuan tentang bentuk pengembangan bakat, pendidikan psikomotor basic dan sikap sehari-hari yang tertuju pada menciptakan suatu ide dan gagasan dalam menciptakan suatu karya yang dapat dipasarkan dan layak jual. Setidaknya minimal ada tiga capaian yang bisa diperoleh dalam pelaksanaan kunjungan dunia usaha dan industri yaitu pembukaan wawasan, penanaman sikap dan pembekalan teknis berwirausaha pada bidang tertentu (Indriaturrahmi \& Sudiyatno, 2016). Untuk mencapai ketiga hal tersebut, maka kegiatan kunjungan di dunia dunia usaha dan industri harus diselaraskan pada upaya pembukaan wawasan, penanaman sikap dan pembekalan teknis berwirausaha. Kunjungan ke dunia usaha dan industri merupakan usaha dalam upaya memperluas wawasan pengetahuan lingkungan kerja, memotivasi siswa memiliki keinginan bekerja mendirikan usaha sendiri, bagaiman memberikan bekal ilmu tentang bagaimana cara bekerja dengan benar, memupuk rasa kedisiplinan dan tanggungjawab dalam melaksanakan tugasnya, menyaksikan secara langsung bagaimana proses produksi baik barang maupun jasa dari barang mentah, setengah jadi dan menjadi barang jadi yang siap digunakan oleh konsumen, dan 
bagaimana pula cara memasarkan sampai ketangan konsumen dengan baik dan benar oleh siswa.

e. Pembimbingan proposal usaha siswa

Proposal Usaha Siswa merupakan proposal yang dimaksudkan untuk memberikan gambaran secara jelas tentang usaha yang akan dilakukan oleh siswa. Dalam hal ini akan diuraikan apa bidang usaha yang dilaksanakan oleh siswa. Proposal usaha ini digunakan secara kelompok yang memuat tentang profil bidang usaha, estimasi peluang dan ancamannya, bagaimana permodalannya, pengelolaanya, pemasaran dan suplayer bahan baku secara detail (Katz et al., 2016). Ada beberapa manfaat yang dapat diambil proposal usaha yaitu : sebagai sarana untuk melakukan analisis aspekaspek usaha yang akan dijalankan, landasan atau acuan seorang pengusaha dalam menjalankan bisnisnya, untuk membantu pengusaha dalam menguji dan mengembangkan strategi usaha yang dijalankan apakah sesuai dengan harapan, sebagai media informasi dan komunikasi bagi pihak-pihak yang akan menjadi mitra bisnis, sebagai media informasi mengenai sumber-sumber finansial serta dokumen penting mengenai evaluasi finansial di masa mendatang.

Manfaat proposal usaha yang pertama adalah untuk membantu wirausahawan untuk dapat berpikir kritis dan objektif atas bidang usaha yang akan dimasukinya. Proposal usaha adalah dokumen tertulis yang disiapkan oleh wirausahawan yang menggambarkan semua unsur yang relevan, baik internal maupun eksternal, mengenai usaha atau proyek baru, atau dapat dikatakan bahwa proposal usaha merupakan dokumen tertulis yang berisi mengenai usaha baru yang sedang direncanakan. Proposal usaha sangat membantu siswa dalam berwirausaha (Elliott et al., 2020). Proposal merupakan suatu rangkuman rencana usaha dan gagasan pemikiran yang bersifat teoritis. Keseluruhan isi proposal usaha mendorong wirausahawan untuk menganalisis keseluruhan aspek usaha dan mempersiapkan alternatif strategi yang efektif untuk menghadapi situasi yang ada.

Proposal usaha sangat membantu kita dalam berwirausaha. Proposal merupakan suatu rangkuman rencana usaha dan gagasan pemikiran yang bersifat teoritis. Keseluruhan isi proposal usaha mendorong wirausahawan untuk menganalisis keseluruhan aspek untuk:

1) Kesesuaian jenis usaha siswa dengan kompetensi mata pelajaran Prakarya dan kewirausahaan yang diselenggarakan sekolah 
2) Kelayakan usaha yang mencakup : biaya produksi, masa produksi, inovasi, kreatifitas dan pemasaran.

3) Pelaksanakan produksi, promosi dan pemasaran.

4) Masa produksi, promosi dan pemasaran disesuaikan dengan jenis usaha yang dipilih (minimal dalam satu semester menghasilkan satu produksi)

5) Kegiatan gebmyar PKWU dengan bazar pada akhir semester

f. Pembentukan kelompok usaha siswa (KUS)

Pembentukan kelompok usaha siswa di harapkan mampu bekerja sama mewujudkan usaha yang baik, dalam kelompok tentu diharapkan sudah mempersiapkan proposal usaha (plan) apa yang harus di persiapkan. Selain hal tersebut juga tidak kalah pentingnya adalah bagaimana melakukan suatu pembagian tugas (organizing) dalam kelompok tersebut (Grohs et al., 2017). Kelompok usaha siswa terdiri dari 5-6 anggota yang di ketua merangkap anggota. Kemudian memusyawarhkan bidang apa yang akan dilakukan dengan pilihan kerajinan, budidaya, rekayasa dan pengolahan. Pada kegiatan KUS ini, seluruh siswa kelas X dibagi menjadi 40 Kelompok Usaha Siswa, dan mereka diajarkan bagaimana seorang wirausahawan yang baik dan memahami keadaan. Setelah proposal disetujui oleh guru pembimbing, mereka diberikan modal sebesar Rp 1.000.000,- per KUS yang nantinya akan mereka gunakankan untuk modal wirausaha mereka dengan menciptakan produkproduk yang inovatif dan kreatif. Meskipun demikian mereka tidak berjalan sendiri, mereka setiap KUS juga dibimbing oleh satu guru pendamping yang merupakan bapak ibu guru di SMA negeri 2 banguntapan. Jadi, pada intinya, event KUS ini bermanfaat untuk siswa dan bapak ibu guru. Setelah melakukan kegiatan wirausaha selama kurang lebih 2 bulan sejak Agustus, pada hari ini seluruh KUS yang ada di SMAN 2 Banguntapan melakukan bazaar di halaman sekolah, yang mana merupakan ajang untuk launching event KUS kepada orangtua mereka masing-masing. Kegiatan bazaar (ekspo) event ini dilaksanakan bulan Desember sebagai akhir dari proses awal sampai akhir dan puncaknya di kegiatan bazaar. Setiap pengunjung pameran dalam bazaar mencoba produk-produk dari KUS di sini, langsung di kampus SMA Negeri 2 Banguntapan menyaksikan kegiatan bazaar mulai dari wali murid, siswa, tokoh masyarakat, tamu undangan lainnya di sekitar sekolah.

g. Implementasi kewirausahaan pameran karya siswa melalui bazar

SMA Negeri 2 Banguntapan Bantul adalah SMA yang mendukung penuh pengembangan kreatifitas peserta didik disegala bidang. Bukan hanya di akademik saja, namun juga di non-akademik. Salah satu bentuk dukungan sekolah terhadap pengembangan non- 
akademik siswa adalah disediakannya sebuah kegiatan dalam bentuk Pameran, Bazar. Dalam kegiatan tersebut, peserta didik dapat mencurahkan segala kemampuan yang dimiliki sesuai dengan passion dan minat mereka. Hal ini dilakukan dengan penuh tanggung jawab dan suka cita.

Peserta didik yang memiliki karya siswa atau kemampuan di bidang kerajinan, pengolahan, budidaya dan rekayasa (gambar, membuat kerajianan tangan/handmade) dapat memilih dan menentukan pameran sebagai fokus kreasi. Sedangkan peserta didik yang menguasai tentang boga/ memasak atau pandai dibidang penjualan dapat bergabung ke kelompok bazar. Bazar disini tidak hanya makanan dan minuman saja. Peserta didik juga dapat menjual hasil karya yang telah dibuat atau hanya sekedar menjadi reseller (penjual pihak ke-dua). Tentu saja sekolah tidak hanya menyediakan pilihan bidang kreatifitas dan bakat ini sesuai kesepakatan antara kelompok siswa dengan pembimbing. Masing-masing dari bidang mempunyai pembimbing yang kompeten sesuai kompetensinya. Sehingga peserta didik tidak berjalan sendiri, tapi bersatu padu menciptakan sebuah Pameran, Bazar yang menunjukan hasil karya siswa dalam bidang prakarya dan kewirausahaan.

Pelaksanaan Pameran, Bazar dilaksanakan setiap akhir semester dan pada event-event tertentu yang mana mengundang banyak orang, seperti wali murid, komite ataupun alumni. Persiapan Pameran, Bazar dan Penta Seni dilakukan menyesuaikan dengan kondisi sekolah. Jika dilaksanakan bertepatan dengan berakhirnya program kewirausahaan. Namun jika Pameran, Bazar juga dapat dilaksankan berbarengan dengan mempertingati event tertentu (ulang tahun sekolah, dll), maka persiapan akan dilaksanakan setelah pulang sekolah tanpa mengganggu jam belajar peserta didik.

Pameran, Bazar dan Penta Seni mendapat sambutan sangat baik dari berbagai kalangan. Mulai dari guru non-pembimbing kegiatan, wali murid, komite bahkan pengawas sekolah. Hal ini dikarenakan, kegiatan Pameran Bazar tidak hanya sebagai kegiatan unjuk kreatifitas, namun juga kegiatan yang menunjukan prestasi dan kemampuan dalam membuat rintisan usaha dan pembelajaran bersosial bagi peserta didik. Dengan adanya kegiatan Pameran, Bazar dan Penta Seni, peserta didik dapat: 1)mengembangkan pengendalian atas emosi pribadi, 2)belajar bersosialisasi positif, 3)mengembangkan kemampuan komunikasi, 4)eksplor beragam karya siswa, 5)belajar bertanggung jawab dalam melaksanakan tugas program kewirausahaan.

h. Penyusunan laporan dan dokumentasi

Membuat laporan kerap kali dilakukan dalam mengerjakan tugas laporan peraktek atau laporan kegiatan yang ditugaskan oleh guru di sekolah. Laporan harus mempunyai format 
penulisan yang baik. Selain itu, isi yang mudah dipahami sudah menjadi keharusan agar pembaca mengerti apa yang dimaksud dalam isi laporan tersebut, sehingga pembaca akan antusias membacanya. Laporan adalah segala sesuatu, baik itu peristiwa ataupun kegiatan yang dilaporkan dan dapat berbentuk lisan ataupun tertulis berdasarkan fakta atau peristiwa yang terjadi. Ada beberapa jenis laporan, seperti laporan perjalanan, laporan penelitian, dan laporan perjalanan. Hakikatnya, laporan perjalanan adalah cerita tentang perjalanan yang kita lakukan. Didalamnya termasuk laporan non-formal karena tidak menggunakan sistematika standar laporan resmi. Laporan kegiatan makanan khas daerah dibuat dalam bentuk proposal. Proposal yang dibuat pada laporan kegiatan makanan bermanfaat untuk beberapa hal seperti berikut.1)membantu wirausaha untuk mengembangkan usahanya serta menguji strategi serta hasil yang diharapkan dari sudut pandang pihak lain (investor). 2)membantu wirausaha untuk berpikir secara kritis dan obyektif atas bidang usaha yang akan dijalankan. 3)sebagai alat komunikasi dalam pemaparan dan meyakinkan gagasan kepada pihak yang lain 4).membantu meningkat kan keberhasilan para wirausaha 5).menganalisis Laporan Kegiatan Usaha Laporan adalah alat pemberitahuan dari suatu tim kerja yang disusun dengan lengkap, sistematis, serta kronologis. Laporan adalah suatu keterangan akan suatu peristiwa atau perihal yang ditulis berdasarkan berbagai data, fakta, dan keterangan yang melingkupi peristiwa atau perihal tersebut.

Setiap kelompok usaha siswa yang telak melaksanakan bazar pada akhir periode langkah selanjutnya adalah dengan membuat laporan kegiatan program kewirausahaan dilengkapi dengan dokumen yang telak dilaksanakan. Adapun laporan tersebut berisi sesuai dengan proposal usaha yang diajukan dengan dilengkapi hasil pencapaian yang telah diraih. Antara lain meliputi latarbelakang maslah, tujuan usaha, pelaksanaan kegiatan. Bab pembahasan mengenai bagaimana mengenai bahan baku, proses produksi, pengemasan produk, melakukan pemasaran produk, biaya produksi, laporan keuangan mendapatkan keuntungan atau kerugian, hambatan dan kendala yang dihadai oleh siswa. untuk bab selanjutnya berisi tentang kesimpulan dan saran dari setiap kelompok dan dilampirkan foto kegiatan program kewirausahaan mulai dari awal sampai dengan akhir kegiatan.

\section{SIMPULAN}

Dalam penelitian ini menunjukan bahawa Implementasi program kewirausahaan di SMA Negeri Banguntapan 2 Bantul sudah berjalan dengan baik. Hal tersebut dilakukan sudah sesuai dengan harapan dalam konsep rumusan program kewirausahaan melalui beberapa tahapan diantaranya melakukan persiapan serta perencanaan, melakukan 
sosialisasi dan motivasi dari praktisi wirausahawan, kunjungan ke dunia usaha dan industri (DUDI), Pembimbingan proposal usaha siswa, pembentukan kelompok usaha siswa (KUS), melakukan bazar dan membuat laporan serta dokumentasi. Program kewirausahaan ini sangat bermanfaat bagi siswa yang untuk mempersiapkan sikap mental siswa setelah lulus sekolah dapat membuka usaha sendiri berwirausaha mencitakan lapangan pekerjaan sendiri dan tidah hanya menggantungkan menjadi pegawai atau karyawan semata, selain dapat membantu diri sendiri juga membantu orang lain dalam upaya mengentaskan dari pengangguran.

\section{SARAN}

Adapun beberapa saran untuk program kewirausahaan ini adalah sebagai diantaranya:

a. perlu adanya dukungan motivasi orangtua siswa, dengan kesadaran bahwa program ini bertujuan untuk mempersiapkan siswa dalam menghadapi kehidupan nyata di masyarakat dengan membuka usaha, sehingga diharapkan dengan pemahaman yang sama antara sekolah dan orangtua sehingga memahami program kewirausahaan tidak untuk membebani siswa.

b. perlu diadakan sosialisasi kepada peserta didik di tingkat Sekolah Dasar dan lanjutan bahwa wirausaha adalah tidak hanya berdagang semata, namun semua produksi, budidaya, kerajinan dan lain sebagainya yang layak untuk dijual dan di optimalkan sehingga membuka lapangan pekerjaan dan menghasilkan pendapatan juga termasuk wirausaha baik dalam bentuk barang maupun jasa.

c. Terbatasnya waktu yang dilakukan sehingga belum optimal dalam menjalankan latihan wirausaha, perlu adanya penambahan waktu agar dan program berkelanjutan sehingga setelah selesai belajar di SMA siswa masih memiliki sikap mental dan berkeinginan menjadi seorang wirausaha dikemuan hari.

\section{DAFTAR PUSTAKA}

Ács, Z. J., Szerb, L., Lafuente, E., \& Lloyd, A. (2018). The Global Entrepreneurship and Development Index. 1990, 21-37. https://doi.org/10.1007/978-3-030-03279-1_3

Amirin, M. Tatang. 1995. Menyusun Rencana Penelitian. Jakarta: PT Raja Grafindo Persada

Arikunto, Suharsimi \& Lia Yuliana. 2009. Manajemen Pendidikan. Yogyakarta. Aditya Media. 
Chu, T., \& Wen, Q. (2019). Does College Education Promote Entrepreneurship in China? Journal of Labor Research, 40(4), 463-486. https://doi.org/10.1007/s12122-019$\underline{\text { 09293-0 }}$

Demircioglu, M. A., \& Chowdhury, F. (2020). Entrepreneurship in public organizations: the role of leadership behavior. Small Business Economics. https://doi.org/10.1007/s11187-020-00328-w

Djumbur. 1975. Bimbingan dan Penyuluhan di Sekolah. Bandung. CV Ilmu.

Elliott, C., Mavriplis, C., \& Anis, H. (2020). An entrepreneurship education and peer mentoring program for women in STEM: mentors' experiences and perceptions of entrepreneurial self-efficacy and intent. International Entrepreneurship and Management Journal, 16(1), 43-67. https://doi.org/10.1007/s11365-019-00624-2

Feriyanto, Andri dan Shyta, Endang Triana. 2015. Pengantar Manajemen (3 in 1). Kebumen: Mediatera.

Fitri, R. P. (2017). Implementasi Pembelajaran Mata Kuliah Kewirausahaan Untuk Meningkatkan Minat Mahasiswa Berwirausaha Prodi Pendidikan Ekonomi IKIP PGRI Bojonegoro. 26-36.

George R. Terry. 1997. Principles Of Management, seventh Edition, Richard D. Irwin, Inc, Homewood, Illionis.

Indriaturrahmi, I., \& Sudiyatno, S. (2016). Peran Dunia Usaha Dan Dunia Industri Dalam Penyelenggaraan Smk Berbasis Kearifan Lokal Di Kota Mataram. Jurnal Pendidikan Vokasi, 6(2), 162. https://doi.org/10.21831/jpv.v6i2.6277

Kang, Y., \& Lee, K. (2020). Designing technology entrepreneurship education using computational thinking. Education and Information Technologies. https://doi.org/10.1007/s10639-020-10231-2

Katz, J. A., Hanke, R., Maidment, F., Weaver, K. M., \& Alpi, S. (2016). Proposal for two model undergraduate curricula in entrepreneurship. International Entrepreneurship and Management Journal, 12(2), 487-506. https://doi.org/10.1007/s11365-014$\underline{0349-9}$

Kemendikbud. 2013. Buku Guru Prakarya. Jakarta: Politeknik Negeri Media Kreatif

Marzuki. 2000. Metologi Riset. Yogyakarta: PT Prasetia Widia Pratama.

Miles and Hubermaqn. 1984. Qualititative Data Analysis A Sorcebook of New Metodes. London. Sage Publication.

Moleong. 2009. Metodologi Penelitian Kualitatif. Bandung. Remaja Rosdakarya. 2011. Metodologi Penelitian Kualitatif. Bandung. Remaja Rosdakarya. 
Senzaki, N. N. (2019). No Titיליle. ペインクリニック学会治療指針 2, February, 1-9. https://doi.org/.1037//0033-2909.I26.1.78

Sudarwan, Danim. 2002. Menjadi Peneliti Kualitatif. Bandung. Pustaka Setia.

Sugiyono. 2011. Metode Penelitian Kuantitatif, Kualitatif, dan R\&D. Bandung. Alfabeta, 2011.

Sugiyono. 2013. Metode Pendidikan Pendekatan Kuantitatif, Kualitatif, dan R\&D. Bandung. Alfabeta.

Sugiyono. 2017. Metode Penelitian. Bandung. Alfabeta.

Suherman, Eman. 2010. Desain Pembelajaran Kewirausahaan. Bandung. Alfabeta.

Sun, D., Li, S., \& Xu, X. (2020). Analysis of reform and development strategies of China's Internet innovation and entrepreneurship education. Entrepreneurship Education, 3(1), 77-93. https://doi.org/10.1007/s41959-020-00024-6

Thomas W Zimmerer 2011. Kewirausahaan. Yogyakarta. Penerbit CV Andi Offset. (2009:54).

Wahidmurni. 2010. Evaluasi Pembelajaran Kompetensi dan Praktik. Yogyakarta. Nuha Liters.

Wahyu, Catarina. 2016. Pengembangan Model Pembelajaran Prakarya Dan Kewirausahaan Dengan Prinsip The Great Young entrepreneur Di SMK untuk Kurikulum 2013. Yogyakarta: Jurnal Pendidikan Vokasi Volume 6 (No.1).

Wanadiana, 2010. Pengaruh dan Fungsi Pengarahan. Bandung: Institute Teknologi bandung.

Widiyarini. (2018). Mengurangi Pengangguran Terdidik dengan Meningkatkan Semangat Kewirausahaan Melalui Pelatihan Jasa Laundry. Sosio E-Kons, 10(3), 199-206. https://doi.org/10.30998/sosioekons.v10i3.2844

Winardi. 2003. Entrepreneur \& Entrepreneurship. Jakarta. Kencana Prenada Media Group.

Winardi. 2016. Kepemimpinan dalam Manajemen. Jakarta. PT. Rineka Cipta.

Ács, Z. J., Szerb, L., Lafuente, E., \& Lloyd, A. (2018). The Global Entrepreneurship and Development Index. 1990, 21-37. https://doi.org/10.1007/978-3-030-03279-1_3

Chu, T., \& Wen, Q. (2019). Does College Education Promote Entrepreneurship in China? Journal of Labor Research, 40(4), 463-486. https://doi.org/10.1007/s12122-01909293-0

Demircioglu, M. A., \& Chowdhury, F. (2020). Entrepreneurship in public organizations: the role of leadership behavior. Small Business Economics. https://doi.org/10.1007/s11187-020-00328-w 
Elliott, C., Mavriplis, C., \& Anis, H. (2020). An entrepreneurship education and peer mentoring program for women in STEM: mentors' experiences and perceptions of entrepreneurial self-efficacy and intent. International Entrepreneurship and Management Journal, 16(1), 43-67. https://doi.org/10.1007/s11365-019-00624-2

Fitri, R. P. (2017). Implementasi Pembelajaran Mata Kuliah Kewirausahaan Untuk Meningkatkan Minat Mahasiswa Berwirausaha Prodi Pendidikan Ekonomi IKIP PGRI Bojonegoro. 26-36.

Grohs, S., Schneiders, K., \& Heinze, R. G. (2017). Outsiders and Intrapreneurs: The Institutional Embeddedness of Social Entrepreneurship in Germany. Voluntas, 28(6), 2569-2591. https://doi.org/10.1007/s11266-016-9777-1

Indriaturrahmi, I., \& Sudiyatno, S. (2016). Peran Dunia Usaha Dan Dunia Industri Dalam Penyelenggaraan Smk Berbasis Kearifan Lokal Di Kota Mataram. Jurnal Pendidikan Vokasi, 6(2), 162. https://doi.org/10.21831/jpv.v6i2.6277

Kang, Y., \& Lee, K. (2020). Designing technology entrepreneurship education using computational thinking. Education and Information Technologies. https://doi.org/10.1007/s10639-020-10231-2

Katz, J. A., Hanke, R., Maidment, F., Weaver, K. M., \& Alpi, S. (2016). Proposal for two model undergraduate curricula in entrepreneurship. International Entrepreneurship and Management Journal, 12(2), 487-506. https://doi.org/10.1007/s11365-0140349-9

Senzaki, N. N. (2019). No Titיליle. ペインクリニック学会治療指針 2, February, 1-9. https://doi.org/.1037//0033-2909.I26.1.78

Sun, D., Li, S., \& Xu, X. (2020). Analysis of reform and development strategies of China's Internet innovation and entrepreneurship education. Entrepreneurship Education, 3(1), 77-93. https://doi.org/10.1007/s41959-020-00024-6

Widiyarini. (2018). Mengurangi Pengangguran Terdidik dengan Meningkatkan Semangat Kewirausahaan Melalui Pelatihan Jasa Laundry. Sosio E-Kons, 10(3), 199-206. https://doi.org/10.30998/sosioekons.v10i3.2844

Yue, Y. U. G.-, Dong, Z. H.-, Ling, Z. C.-, He, W., Protection, E., Academy, B., Science, F., Forest, P., Management, P., Station, Q., Bureau, C., Management, F. P., \& Station, Q. (2017). 北京 “松黑木吉丁”或 “松迹地吉丁”学名考 $1 * 23$. $39(1), 1-4$. 